ACTA THERIOLOGICA

Vol. 29, 24: 291-295, 1984

\title{
Observations on Recovering and Freezing Red Deer Embryo
}

\author{
A. KRZYWIŃSKI, E. WIERZHOŚ \& Z. SMORĄG
}

\begin{abstract}
Krzywiński A., Wierzchoś E. \& Smorąg Z., 1984: Observations on recovering and freezing red deer embryo. Acta theriol., 29, 24: 291-295 [With 2 Tables \& Plates II-III]

Experiments on embryo transfer was carried out from 1981 to 1982 on a total number of 7 hinds. In four hinds for oestrus synchronisation prostaglandin were used. Various doses of PMSG were given to stimulate superovulation. In three hinds the spontaneous oestrus were utilized. One embryo was frozen for later transfer. Oestrus occurred in operated hinds in the same reproductive season and they were mated. Theoretically it seems that by embryo transfer the numbere of individuals of rare species and subspecies could be relatively quickly increased. The freezing of embryos and their storage in banks would ensure existance of a given species even in case of its extinction.

[Polish Acad. Sci., Inst. of Genetics and Animal Breeding, Popielno, 12-222 Wejsuny (AK) and Dept. of Physiology and Artificial Insemination of Inst. of Zootechnics, 32-083 Balice (EW, ZS)].
\end{abstract}

\section{INTRODUCTION}

Presently as many as 29 species and subspecies of deer alive today are threatened with extinction (recorded in the Red Data Book, IUCN). In some cases the number of individuals of certain species and subspecies is very limited. Breeding such small groups of animals has negative inbreeding effects and can even be responsible for the extinction of some species in the near future. One such example is the Schomburgk's deer (Cervus schomburgki Blyth, 1963). The last Schomburgk's deer in captivity died in 1911 while the last Schomburgk's deer in the wild was shot in 1938 (Frädrich, 1980). Significant progress in domestic animal reproduction suggests that both semen freezing and embryo transfer can have practical application in protecting animals threatened with extinction. At the moment these methods are used in preventing the total loss of rare breeds of domestic animals. Not only have semen banks been established but also frozen embryo banks (Betteridge, 1977; Seidel, 1981). It would seem that to protect rare deer species these zootechnical methods could be used. The importance of freezing semen and embryo transfer was widely discussed at the 1st International Symposium on Artificial Breeding of Non-Domestic Animals in 1977 in London (Polge, 1978). The fact, that experiments with wild animals create many additional problems was taken into consideration.

In deer, the usefulness of opening semen banks was stressed at deer wo:kers meetings in Longview, USA -1977 (Whitehead, 1978) and in Front Royal, USA - 1982. 


\section{MATERIAL AND METHODS}

The experiment was carried out from 1981 to 1982 on a total of seven hinds that had been hand reared on milk and very tame. The animals were 1.5 to 3.5 years old (Table 1 and 2) and were kept at the deer farm at Wejsuny (Research Station PAS - Popielno), in approximately 80 ha of enclosed forest. Before the rutting season the females were herded into a 0.5 ha enclosure. The occurrence of oestrus was checked every day with a vasectomized stag from the middle of September until oestrus was observed.

a. The preparation of the animals for the experiment. In 1981 four hinds (Group I) with closely occurring oestrous cycles were used as donors. They were used for oestrous synchronization and superovulation. To synchronise oestrus each hind was given intramuscularly $1 \mathrm{ml}$ prostaglandin (Estrumate - producer: Imp. Chem. Industr. Ltd, G.B.). Superovulation was stimulated during the 7th to 14 th day of oestrous cycle with $750-1750$ i.u. PMSG (Serogonadotropin, producer: Polfa). The hinds were then mated two times with checked stags and operated on 6 days after mating.

In 1982, three hinds (Group II) were used. When oestrus was observed each hind was mated during spontaneous cestrus without attempting to stimulate superovulation. The hinds were operated on 7 days after mating.

b. The operation. The uterus was flushed using a method similar for sheep. About $15 \mathrm{~min}$. before the operation the hind was given 0.7 to $1.5 \mathrm{ml}$ rompun Producer: Bayer), in a $10 \%$ solution according to the deer's weight and degree of tameness. The animal was placed on the operating table on its back (Photo 1, Plate II). The operating field was prepared according to generally accepted principles. Local anaesthesia was done with $29 \%$ polocain before the incision was made. The stomach integument was cut along the white line about $4 \mathrm{~cm}$ from the milk gland. When the peritoneum had been cut about $8 \mathrm{~cm}$ in the direction of the stomach cavity the fundus uteri and the cornu were grasped with two fingers. When the uterus had been pulled outside (Photo 2), a catheter $2.5 \mathrm{~mm}$ in diameter (Photo 3, Plate III), was introduced into the oviduct entering from the side of the ovaries. To obtain the embryos the uterine horn was flushed with Dulbecco solution. Approximately $20 \mathrm{ml}$ of the fluid was introduced with a dull needle into the end where the uterus divided. Both horns were flushed in stimulated for superovulation animals while only the horn with a yellow body was flushed in animals having spontaneous oestrus. When flushing was completed the uterus was reintroduced into the stomach cavity. Two types of stitching were used: continuous no. 1 with catgut for the peritoneum and muscle and knots no. 2 with catgut for the skin. Two hinds started to wake up before the operation was completed and were given additional combelen $(3 \mathrm{mI})$. The hinds woke up with 30 to $40 \mathrm{~min}$. and lay with head up.

c. Treatment of embryos. The Dulbecco solution used to flush the horn was collected onto concave plates usually used for embryos of domestic animals. These plates were placed in a temperature controlled chamber and examined with a stereoscopic microscope. Upon recovering and evaluating the embryos they were frozen in the same way as cattle embryos are frozen (Smorag, 1982).

\section{RESULTS}

Table 1 shows the results of flushing the uterine horn of hinds after stimulating superovulation with PMSG, Table 2 - hinds having spontaneous oestrus. In group I of the four hinds stimulated for superovu- 
lation hind no. 10 could not be operated on due to the lack of transportation to the site of the operation when required. This hind calved one fawn on the expected due date. It should be noted that this hind received the smallest dosage of PHSG (750 i.u.). The remaining three hinds which were operated and had numerous unbroken follicles and two of them had the deteriorating yellow bodies (1 and 2$)$. In hind that received the largest dose of PMSG (1750 i.u.) no ovulation occurred. No embryo were obtained in this group. The morphology of the ovaries with many broken follicles and questionable oestrus may indicate that the process

Table 1

Attempts of embryo obtaining after oestrus synchronization and stimulated superovulation (experiment in 1981).

\begin{tabular}{|c|c|c|c|c|}
\hline \multirow{2}{*}{ Items } & \multicolumn{4}{|c|}{ No. of hind } \\
\hline & 11 & 13 & 27 & 10 \\
\hline $\begin{array}{l}\text { Age, years } \\
\text { PMSG treatment }\end{array}$ & 2.5 & 3.5 & over 10 & 2.5 \\
\hline $\begin{array}{l}\text { Date } \\
\text { Dose, i.u. }\end{array}$ & $\begin{array}{l}5 \mathrm{Dec} . \\
1750\end{array}$ & $\begin{array}{l}5 \text { Dec. } \\
1200\end{array}$ & $\begin{array}{l}5 \mathrm{Dec} . \\
1000\end{array}$ & $\begin{array}{l}4 \mathrm{Dec} . \\
750\end{array}$ \\
\hline $\mathrm{PGF}_{2}$ treatment & & & & \\
\hline $\begin{array}{l}\text { Date } \\
\text { Dnse, } \mathrm{ml}\end{array}$ & ${ }_{1}^{7}$ Dec. & $7 \underset{1}{\mathrm{Dec}}$ & $7 \underset{1}{7}$ Dec. & $6 \underset{1}{\text { Dec. }}$ \\
\hline $\begin{array}{l}\text { Date of mating } \\
\text { Date of flushing the }\end{array}$ & 10-11 Dec. & 10 Dec. & $10 \mathrm{Dec}$. & 8 Dec. \\
\hline $\begin{array}{l}\text { uterine horns } \\
\text { No. of corpora lutea }\end{array}$ & ${ }_{0}^{16}$ Dec. & $\begin{array}{l}16 \text { Dec. } \\
2\end{array}$ & 16 Dec. & - \\
\hline Results of flushing & - & 0 & 0 & - \\
\hline
\end{tabular}

Table 2

Attempts of embryo obtaining after spontaneous oestrus (experiment in 1982).

\begin{tabular}{|c|c|c|c|c|c|}
\hline $\begin{array}{l}\text { Name } \\
\text { of } \\
\text { hind }\end{array}$ & $\begin{array}{l}\text { Age, } \\
\text { years }\end{array}$ & $\begin{array}{c}\text { Date of oestrus } \\
\text { occurrence and } \\
\text { mating }\end{array}$ & $\begin{array}{l}\text { Date of flushing } \\
\text { the uterine horn }\end{array}$ & $\begin{array}{l}\text { No of } \\
\text { corpora } \\
\text { lutea }\end{array}$ & $\begin{array}{l}\text { Results } \\
\text { of } \\
\text { flushing }\end{array}$ \\
\hline Sylvia & 1.5 & 4 December & 10 December & 1 & \multirow{3}{*}{$\begin{array}{l}\text { one embryo } \\
\text { one zona } \\
\text { pellucida only }\end{array}$} \\
\hline No. 12 & 4.5 & 10 December & 17 December & 1 & \\
\hline Saba & 1.5 & 10 December & 18 December & 1 & \\
\hline
\end{tabular}

did not occur properly. Results were much worse that those obtained by Kelly and Moore (1977) who superovulated hinds to obtain twins. This could have been caused by the too large PMSG dosage. There were no post-operational complications. Two hinds came in oestrus in the same season, were mated and gave birth to fawns, while the other one was barren.

In group II of the three hinds, not stimulated for superovulation, operated on in 1982 one embryo in the morula stage (Photo 4) and one empty zona pellucida were recovered. No embryo was found in the 
third hind. The cloudy fluid with blood elements which was obtained suggested an infected uterus. All hinds came in oestrus in an approximately 18 day of cycle (11 days after the operation) and during the same season were mated. The flushing results of these hinds were rather positive.

The embryo that was found (Photo 4) was in the late morula stage. The morphological state of the embryo, determined according to criteria used for evaluating sheep and cattle embryos, was satisfactory. Attention should be paid to the transparent integument, its eliptical shape and thinness, all of which are characteristic of embryos in later stages of development. This state characterizes embryo in the late blastocyst stage just before the integument is lost. After recovering and evaluating the embryo it was frozen according to methods used for freezing cattle embryos (Smorąg, 1982). After freezing the embryo was placed in a bank for later transfer.

\section{DISCUSSION}

Only one embryo was obtained during this experiment. The fact that during the same season the hinds had repeated oestrus and were mated shows that the treatment had no negative effects on the reproductive processes. However it made it possible to obtain an additional embryo from one hind during one year. This creates the possibility of recovering additional numbers of offspring from females of species threatened with extinction. This is very significant in terms of their protection and breeding. It would appear that this method could be used to increase the population of rare subspecies of deer. The common Cervus elaphus hippelaphus Erxleben, 1777 could be used as a recipient, and C. e. bactrianus Lydekker, 1900; C. e. yarkandensis Blanford, 1892 and C. e. corsicanus Erxleben, 1777 as donors. For the common Cervus nippon hortulorum Swinhoe, 1864, the rare C. $n$. keramae (Kuroda, 1924); C. $n$. pseudaxis Eydoux and Souleyet, 1841 and C. $n$. grassianus (Heude, 1884) could be donors. The rare subspecies Dama dama mesopotamica (Brooke, 1875) fould be a donor for the common subspecies D. d. dama (Linnaeus, 1758). The experiments of Allen et al. (1980) in which they transfered donkey embryos into mares and vice versa indicate the possibility of embryo transfer between species even when the differences result in sterile offspring. It seems that research on hybrids between species such as red deer crossed with milu and others would be profitable. The freezing of embryos makes it possible to send them great distances without the necessity of transporting the animals themselves. This avoids the carrying of diseases since embryos can be quarantined. Transfer them to recipients living in a given climate insures that the young adapt themselves to the new conditions. 
It would seem that "genetic banks" of frozen embryos will be immensely important in protecting species in the future since even in instances of a catastrophe, the crossing with another species or an epidemic, it would always be possible to re-establish a given species.

Acknowledgements: The authors thank Professor S. Wierzbowski for the help. and valuable advances.

\section{REFERENCES}

1. Allen W. R., Pashen R. L. \& Willadsen S. M., 1980: Proc. Study Fert., Ann. Conf., Cambridge 33.

2. Betteridge K. J., 1977: Embryo transfer in farm animals. Canada Dept. of Agriculture, Monograph No. 16.

3. Frädrich H., 1980: Breeding endangered cervids in captivity. Int. Zoo Yearbook, 20: $80-89$.

4. Gray A. P., 1972: Mammalian Hybrids. Commonwealth Agric. Bureaux: $\mathrm{X}+1-262$ Edinburgh.

5. Kelly R. W. \& Moore G. H., 1977: Reproductive performance in farmed red deer. N. Z. Agric. Sci., 11: 179-181.

6. Polge C., 1978: Embryo transfer and embryo preservation. Symp. Zool. Soc. Lond., 43: 303-316.

7. Seidel G., 1981: Superovulation and embryo transfer in cattle. Science, 211: $351-358$.

8. Whitehead G. K, 1978: Captive breeding as a practical aid to preventing extinction, and providing animals for reintroduction. IUNC Morges: 353-363.

Accepted, April 12, 1984.

Andrzej KRZYWINSKI, Edward WIERZCHOS i Zdzisław SMORĄG

OBSERWACJE NAD POZYSKIWANIEM I MROZENIEM ZARODKOW JELENIA SZLACHETNEGO

\section{Streszczenie}

Doświadczenia nad transplantacją zarodków byly prowadzone w latach 1981-1982 na siedmiu samicach jelenia szlachetnego. U czterech łań ruję wywołano. przy pomocy prostaglandyny i poddano superowulacji, u trzech lań wykorzystano. ruję spontaniczną (Tabele 1,2 ). Zamrożono jeden zarodek celem późniejszej transplantacji. U samic po operacji jeszcze w tym samym sezonie rozrodczym wystąpiła ruja i zostaly one pokryte. Teoretycznie wydaje się, że przez transplantację zarodków populacje rzadkich gatunków mogłyby stosunkowo szybko wzrosnąć. Mrożenie zarodków i ich przechowywanie w bankach mogłoby zapewnić egzystencję gatunku nawet w przypadku jego wyginięcia. $\mathrm{Na}$ podstawie pracy Gray (1972) można sądzić, że wykorzystanie w praktyce tej metody jest możliwe co najmniej dla 16 gatunków i podgatunków z ogólnej liczby 29 znajdujących. się w Czerwonej Księdze IUCN 


\section{EXPLANATION OF PLATES}

PLATE II

Photo 1. Position of the animal during the surgery.

Photo 2. The uterus of operated hind being pulled outside.

\section{PLATE III}

Photo 3. Flushing of the uterine horn with Dulbecco solution to obtain the embrya. Photo 4. The 6-days-old embryo in the morule stage.

(Photos $1-3$ by A. Turczański, 4 by L. Kątska) 


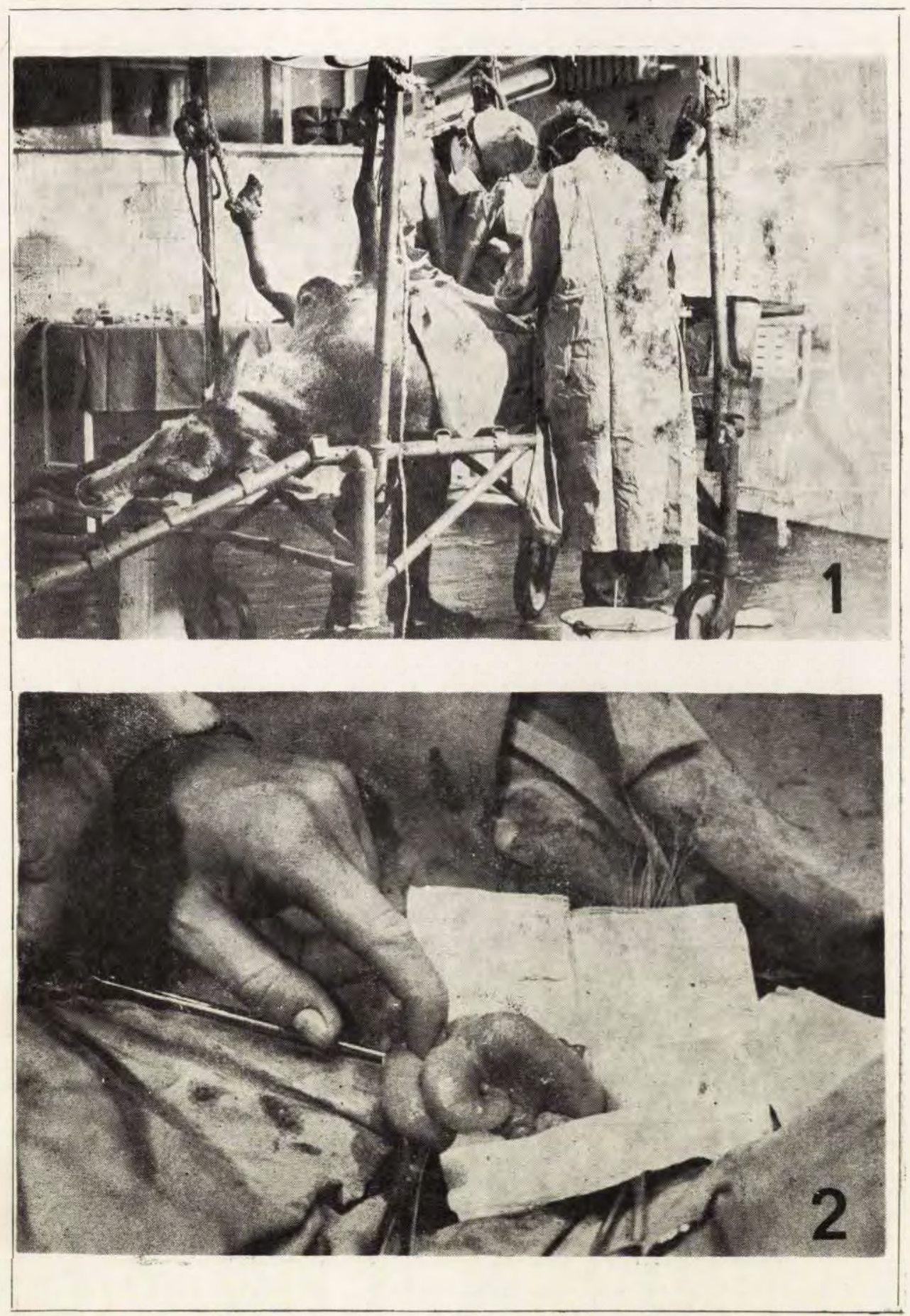



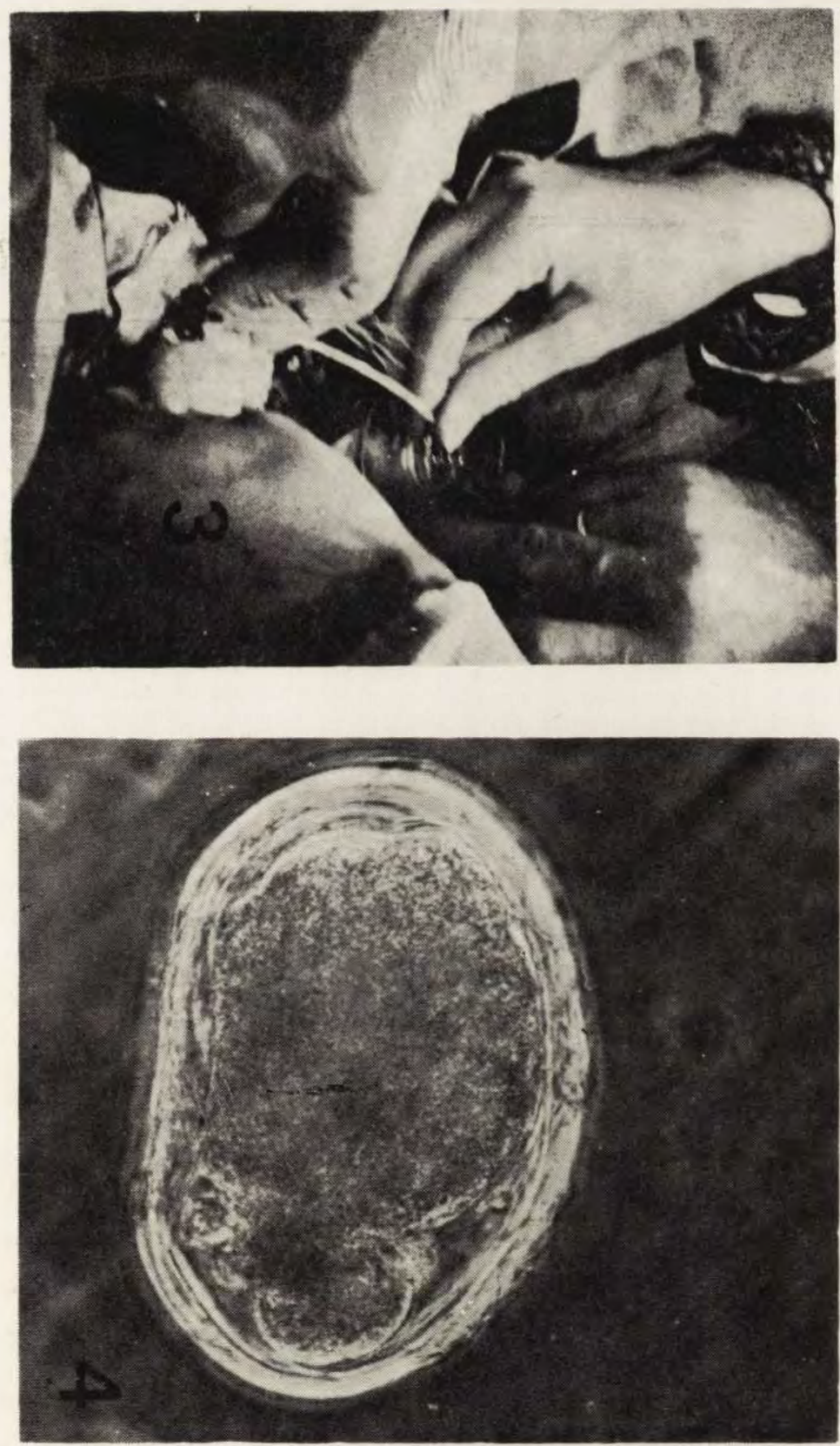